\title{
The multifaceted resources and microevolution of the successful human and animal pathogen methicillin-resistant Staphylococcus aureus
}

\author{
Agnes Marie Sá Figueiredo/ ${ }^{+}$, Fabienne Antunes Ferreira \\ Departamento de Microbiologia Médica, Instituto de Microbiologia Paulo de Góes, \\ Universidade Federal do Rio de Janeiro, Rio de Janeiro, RJ, Brasil
}

\begin{abstract}
Methicillin-resistant Staphylococcus aureus (MRSA) is one of the most important bacterial pathogens based on its incidence and the severity of its associated infections. In addition, severe MRSA infections can occur in hospitalised patients or healthy individuals from the community. Studies have shown the infiltration of MRSA isolates of community origin into hospitals and variants of hospital-associated MRSA have caused infections in the community. These rapid epidemiological changes represent a challenge for the molecular characterisation of such bacteria as a hospital or community-acquired pathogen. To efficiently control the spread of MRSA, it is important to promptly detect the mecA gene, which is the determinant of methicillin resistance, using a polymerase chain reaction-based test or other rapidly and accurate methods that detect the mecA product penicillin-binding protein (PBP)2a or PBP2'. The recent emergence of MRSA isolates that harbour a mecA allotype, i.e., the mecC gene, infecting animals and humans has raised an additional and significant issue regarding MRSA laboratory detection. Antimicrobial drugs for MRSA therapy are becoming depleted and vancomycin is still the main choice in many cases. In this review, we present an overview of MRSA infections in community and healthcare settings with focus on recent changes in the global epidemiology, with special reference to the MRSA picture in Brazil.
\end{abstract}

Key words: methicillin resistance - Staphylococcus aureus - MRSA - HA-MRSA - CA-MRSA

In the early 1940s, before the introduction of penicillin for the treatment of Staphylococcus aureus diseases, bloodstream infections (BSI) caused by this pathogen were often lethal. A study carried out at the Boston City Hospital reported a mortality rate of more than $80 \%$ for a group of 122 cases of S. aureus BSI (Skinner \& Keefer 1941). In 1942, shortly after the introduction of natural penicillin in clinical therapy, the emergency of $S$. aureus isolates displaying resistance to this $\beta$-lactam drug was first reported (Rammelkamp \& Maxon 1942). In the 1960s, approximately $80 \%$ of all clinical isolates of $S$. aureus were $\beta$-lactamase producers (Jessen et al. 1969). Thus, the need for new drugs to treat staphylococcal infections motivated the development of semi-synthetic penicillins containing a $\beta$-lactamase-resistant $\beta$-lactam ring, such as methicillin and oxacillin. However, in the early 1960s, the first isolates of methicillin-resistant $S$. aureus (MRSA) were detected in the United Kingdom (UK) (Jevons 1961).

The starting point for the MRSA evolution was the acquisition of the mecA gene, which encodes an exogenous penicillin-binding protein $(\mathrm{PBP})(78-\mathrm{kDa})$, known

doi: $10.1590 / 0074-0276140016$

Financial support: CNPq, FAPERJ, CAPES, European Commission's (FP7)/Marie Curie International Research Staff Exchange Scheme NANO_GUARD (PIRSES-GA-2010-269138)

+ Corresponding author: agnes@micro.ufrj.br

Received 15 January 2014

Accepted 12 March 2014 as PBP2a or PBP2', which confers resistance to methicillin and cross-resistance to other $\beta$-lactam drugs. This protein is an alternative transpeptidase that has low affinity for $\beta$-lactam antibiotics. Therefore, PBP2a is able to catalyse cell-wall synthesis, even when normal PBPs are covalently linked to $\beta$-lactams (Brown \& Reynolds 1980). The mecA gene is a DNA segment of $2.1 \mathrm{~kb}$ that is non-native to $S$. aureus and is inserted in a large block of exogenous DNA, known as the staphylococcal cassette chromosome mec (SCCmec) (Katayama et al. 2000).

The SCCmec is integrated in the MRSA chromosome at the 3 ' end of open reading frame $\mathrm{X}$ at the specific site attBSCC, which is located near the origin of replication in the staphylococcal chromosome and flanked by direct and repeated sequences. SCCmec carries the mec gene, a region encompassing the $m e c A$ gene and its regulators $m e c R I$ and $m e c I$ and the $c c r$ complexes, the recombinase genes region, which is responsible for SCCmec mobility (Katayama et al. 2000). A number of genetic elements may be present in the SCCmec, including insertion elements such as IS257 and IS431, plasmids such as pUB110 and pT181 and transposons such as Tn554. Thus, some SCCmec can carry genes conferring erythromycin, tetracycline, kanamycin, spectinomycin and tobramycin resistance, in addition to heavy metal detoxification genes. Because of these characteristics, SCCmec can be considered a resistance island. In addition to SCCmec, the presence of copies of IS256 distributed in the S. aureus genome may also provide hot spots for the insertion of other resistance elements (Katayama et al. 2000).

Due to the increasing number of publications reporting new types, subtypes and variants of SCCmec, 
an international working group was created in 2009 to standardise the nomenclature and classification of new SCCmec types [International Working Group on the Classification of Staphylococcal Cassette Chromosome Elements (IWG-SCC)]. All of this information, as well as the characteristics of each type of SCCmec, can be accessed on the IWG-SCC website (sccmec.org). Eleven types and several variants of SCCmec elements have been identified (Table I) and each displays characteristic combinations of the $\mathrm{ccr}$ and mec complexes (Turlej et al. 2011).

The first SCCmec that were described were types I, II and III. Currently, these types are commonly detected in MRSA strains associated with nosocomial infections (Becker et al. 2012, Yamamoto et al. 2012, David et al. 2013, El-Mahdy et al. 2013). The SCCmec type I was initially found in MRSA isolates predominantly in the UK in the 1960s. This SCCmec type contains no antibiotic resistance genes other than mecA (Ito et al. 2001). SCCmec types II and III were first associated with strains that were prevalent during the 1980 s and carry multiple resistance genes (Ito et al. 1999, 2001). The subsequently described SCCmec type IV does not carry an antibiotic resistance gene, except for $m e c A$ and presents a specific combination of the $\mathrm{ccr}$ and mec complexes (Ma et al. 2002). Furthermore, type IV has predominantly been found among MRSA strains associated with community infections. However, isolates of paediatric and EMRSA15 clones can also harbour SCCmecIV and are typically associated with nosocomial infections (de Miranda et al. 2007, Conceição et al. 2013). SCCmecV was first described in 2004 to be associated with MRSA involved in community-acquired infections. This element has no resistance gene other than $m e c A$ and carries $c c r C$ (Ito et al. 2004). The SCCmec type VI was found in some a paediatric isolates from Portugal and France (Oliveira et al. 2006, Dauwalder et al. 2008). SCCmecVII was initially found in an isolate belonging to sequence typing (ST) 5 , which was collected from a community-acquired in- fection in Sweden (Berglund et al. 2008). This last type is similar to SCCmecV in the sense that both carry one copy of $c c r C$, while all other SCCmec types harbour two copies of $c c r A$ and $c c r B$ (Table I). SCCmecVIII was detected among typical hospital isolates in Canada and has a unique combination of mec and $c \mathrm{cr}$ regions (Zhang et al. 2009). Finally, three more types of SCCmec have recently been detected. Li et al. (2011) described types IX and X, which were carried by isolates of ST398 [multilocus sequence typing (MLST) clonal complex (CC) 398 (CC398)] and both presented a number of genes encoding resistance to heavy metals. The last SCCmec described thus far, type XI (harbouring an arsenic resistance operon), was initially reported by Sanger Institute (Hinxton, UK) in ST425 (CC425) MRSA from bovine isolates and subsequently in ST130 (CC130) MRSA from human hospital isolates in the UK (Shore et al. 2011) (Table I).

Four main classes of mec complexes (A, B, C and E) were found among the MRSA strains (Turlej et al. 2011). Class A is the prototype complex and was detected in SCCmecII, III and VIII. This class contains complete $m e c R I$ and the mecI regulatory genes located upstream of $m e c A$ and the hypervariable region (HVR) and IS431 located downstream of mecA. Class B was found in SCCmecI, IV and VI and is composed of a truncated $m e c R I$ (due to the insertion of IS1272) upstream of mecA and HVR and IS431 downstream of mecA. Two types of class $\mathrm{C}$ have been described $(\mathrm{C} 1$ and $\mathrm{C} 2)$ and both contain a truncated mecRI (due to insertion of IS431) upstream of mecA and HVR and IS431 downstream of mecA. In complex $\mathrm{C} 1$ (SCCmecVII and X), the upstream and downstream copies of IS431 are in the same orientation, while, in complex $\mathrm{C} 2$ (SCCmecV and IX), these insertion sequences are reversed. Class E (SCCmecXI) harbours a new mecA allotype known as $m e c C$ (formerly $\left.m e c \mathrm{~A}_{\mathrm{LGA} 251}\right)$ and novel allotypes of the mec regulatory genes that are located upstream of mecC, in addition to a new allotype of blaZ ( $\beta$-lactamase-encoding gene) downstream of mecC (Turlej et al. 2011) (Table I).

TABLE I

Main characteristics of the staphylococcal cassette chromosome mec (SCCmec) of Staphylococcus aureus

\begin{tabular}{lccc}
\hline $\begin{array}{l}\text { SCCmec } \\
\text { types }\end{array}$ & Main sequence typing (ST) involved & Resistance traits & $\begin{array}{c}c c r / m e c \\
\text { complexes }\end{array}$ \\
\hline I & ST5, ST228, ST247 & Only $m e c A$ & A1B1/B \\
II & ST5, ST36 & Antimicrobial resistance genes & A2B2/A \\
III & ST93, ST239 & Antimicrobial resistance genes & A3B3/A \\
IV & ST1, ST5, ST8, ST22, ST30, ST36, ST45, ST59, ST80 & Only $m e c A$ & A2B2/B \\
V & ST1, ST8, ST59, ST152, ST398 & Only $m e c A$ & C1/C2 \\
VI & ST5 & Only $m e c A$ & A4B4/B \\
VII & ST59 & Only $m e c A$ & C1C1 \\
VIII & ST8, ST59 & Only $m e c A$ & A4B4/A \\
IX & ST9, ST398 & Heavy metal resistance genes & A1B2 \\
X & ST398 & Heavy metal resistance genes & A1B6/C1 \\
XI & ST425, ST130 & Arsenic resistance operon & A1B3/E \\
\hline
\end{tabular}


Despite effective antimicrobial therapy, the incidence of this alarming pathogen has continuously increased. In 1970 , it was estimated that MRSA accounted for only $2 \%$ of the S. aureus isolates found in hospitals of different countries (O'Toole et al. 1970). The late 1980s and early 1990s were marked by a rapid, worldwide spread of multiresistant MRSA (Sanches et al. 1995, Teixeira et al. 1995, Mato et al. 1998, Kahla-Clemenceau et al. 1999). By the 2000 s, approximately $60 \%$ of $S$. aureus isolates collected from hospitalised patients in the United States of America (USA) and other countries, including Brazil, were resistant to methicillin (NNIS 2004, Amaral et al. 2005). It is likely that this intensive spread of MRSA has mainly occurred due to selective pressure exerted by the high use of antimicrobial drugs in hospitals around the world (Taubes 2008). However, other factors, including (i) invasive approaches for the diagnostic and therapeutic management of infections, (ii) intrinsic characteristics of patients (including populations with age extremes, immunosuppressive conditions or other underlying diseases) and (iii) virulence traits and fitness advantages of the microorganisms, are expected to have contributed to the leadership position of MRSA as a global hospital pathogen (Amaral et al. 2005, Planet et al. 2013). In Brazil, MRSA was ranked as the first etiologic agent of hospital-associated BSI and second in nosocomial pneumonia (Gales et al. 2009).

In October 2007, it was estimated by the Centers for Disease Control and Prevention (CDC) that the number of infections caused by MRSA should be approximately 100,000 per year in the USA, with nearly 19,000 reported deaths, which is a number that was greater than the total deaths attributed to human immunodeficiency virus/ acquired immune deficiency syndrome in the same year (CDC 2007, Taubes 2008). In Europe, it was reported that MRSA has caused more than 170,000 infections per year, corresponding to $44 \%$ of all infections related to healthcare (ECDC/EMEA 2009). Another study published in 2011 that involved 31 European countries showed that the 27,711 episodes of MRSA BSI were associated with 5,503 deaths and 255,683 days of hospitalisation. The cost related to this length of hospital stay was estimated as 44 million Euros (de Kraker et al. 2011). These data reinforce the importance of these microorganisms as a global public health, social and economic problem.

Remarkably, MRSA has the potential for long-distance clonal spreading (Enright et al. 2000) and specific international clones have been associated with nosocomial [hospital-acquired MRSA (HA-MRSA)] or community infections [community-acquired MRSA (CAMRSA)]. For this reason, genotyping techniques are widely used in epidemiological studies involving these bacteria. Thus, MRSA isolates with similar or even identical backgrounds can be allocated within the same clone or type according to the results of several typing methods. Among these methods, the most used are the analysis of pulsed-field gel electrophoresis patterns (Sanches et al. 1995), MLST, which defines ST and CC (Enright et al. 2000), SCCmec typing (Turlej et al. 2011) and analysis of the polymorphism of the spa gene that codes for protein A (Frénay et al. 1996). Nevertheless,
MRSA lineages are commonly defined by ST associated with the SCCmec type.

The spread of MRSA among pets (including dogs and cats) and farm animals (such as pigs, calves, dairy cattle and horses) has also been reported (Armand-Lefevre et al. 2005, Cuny et al. 2008, Haenni et al. 2012, Quitoco et al. 2013). CC398 MRSA has initially been described among livestock-associated MRSA (LA-MRSA) in Europe (Armand-Lefevre et al. 2005) and has now been detected in different continents from Oceania (Williamson et al. 2013) to South America (Peru) (Arriola et al. 2011). More importantly, infections by CC398 have been reported in humans (Armand-Lefevre et al. 2005, Krziwanek et al. 2009). In contrast to LA-MRSA, the majority of MRSA isolates that have been detected in pets have clustered into the ST observed in CA-MRSA strains commonly detected in humans (Ferreira et al. 2011, Haenni et al. 2012, Loeffler et al. 2013).

Since it was first described in the UK and Denmark in MRSA isolates from cattle harbouring SCCmec type $\mathrm{XI}$, MRSA isolates carrying the $m e c C$ gene have been detected in a number of European countries (Cuny et al. 2011, Garcia-Alvarez et al. 2011, Shore et al. 2011, Laurent et al. 2012, Sabat et al. 2012). More recently, a fatal case of BSI caused by a MRSA harbouring the $m e c C$ gene was described in Spain. This strain was associated with the CC130 lineage and spa type t843 (García-Garrote et al. 2013). In Europe, the mec $C$-MRSA isolates from a range of ST have been found to be associated with infections in a variety of animal species and less frequently in humans (Cuny et al. 2011, Laurent et al. 2012, Paterson et al. 2012). A number of findings have supported the link between humans and livestock animals, strongly suggesting the occurrence of cross-transmission of mecC isolates between these two populations (Garcia-Alvarez et al. 2011, Shore et al. 2011, Sabat et al. 2012, Harrison et al. 2013, Vandendriessche et al. 2013). The rapid spread of the novel $m e c C$ gene in different MRSA strains reinforces the need of control measures to prevent $\mathrm{mecC}$ dissemination. In addition, $m e c C$-positive isolates represent a potential public health problem because the sequence differences between $m e c A$ and $m e c C$ can lead to failure in $m e c$ gene detection when the current tests for detecting methicillin resistance are used (i.e., polymerase chain reaction assays for detecting $m e c A$ and PBP2a latex agglutination tests) (Ito et al. 2012). To the best of our knowledge, no report on the isolation of $m e c C$-harbouring MRSA in Brazil has been published.

HA-MRSA - The highest rates of MRSA in hospitals have been reported in North America, South America and Asia (> 50\%) and intermediate rates (25-50\%) have been found in China, Australia, African countries and in some European countries, for example, Portugal (49\%), Greece (40\%), Italy (37\%) and Romania (34\%). Other European countries (Netherlands and Scandinavian countries) have shown low rates of HA-MRSA that are generally $\leq 1 \%$ (Deurenberg \& Stobberingh 2008, Stefani et al. 2012).

Worldwide, the most frequent $\mathrm{CCs}$ found among HAMRSA isolates are CC5, CC8, CC22, CC30 and CC45. Some CCs may encompass different MRSA clones 
and are distributed in diverse countries and/or regions (Deurenberg \& Stobberingh 2008, Moore et al. 2010, Menegotto et al. 2012, Machuca et al. 2013). The current MRSA lineages and their corresponding clones are shown in Table II. CC5 and CC8 are currently the most prevalent CCs globally (Deurenberg \& Stobberingh 2008, Song et al. 2011, Shittu et al. 2012, Caiaffa-Filho et al. 2013, David et al. 2013, He et al. 2013), while CC30 (ST36) is more commonly detected in the UK (McAdam et al. 2012) and CC45 (ST45) is generally found in the USA and Northern Europe (Moore et al. 2010, Menegotto et al. 2012). However, the most common (typical) HA-MRSA isolates in the USA belong to USA100 clone, which is a CC5 MRSA (ST5) (David et al. 2013). In Asian hospitals, MRSA from CC8 (ST239), CC5 (ST5) and CC22 (ST22) are among the most frequently detected isolates (D'Souza et al. 2010, Ghaznavi-Rad et al. 2010, Song et al. 2011, He et al. 2013). Epidemi- ological data are still limited in Africa; however, the predominance of CC8 (ST239 and ST612), CC5 (ST5) and CC30 (ST36) was suggested (Moodley et al. 2010, Breurec et al. 2011, Van Rensburg et al. 2011, Shittu et al. 2012). In Latin America, isolates belonging to CC5 (ST5) and CC8 (ST239) are frequently reported in hospitals (Silva-Carvalho et al. 2009, Rodríguez-Noriega et al. 2010, Caiaffa-Filho et al. 2013) and, in Brazil, the nosocomial lineages ST5-SCCmecI (Cordobes/Chilean clone), ST5-SCCmecIV (USA800; paediatric clone) and ST5-SCCmecII (USA100; clone NY/Japan) are prevailing in some hospitals (de Miranda et al. 2007, SilvaCarvalho et al. 2009, Becker et al. 2012, Caiaffa-Filho et al. 2013). Moreover, MRSA isolates of the lineage ST239-SCCmecIII [Brazilian epidemic clone (BEC)] are still predominantly detected in various regions of this country (Silva-Carvalho et al. 2009, Caboclo et al. 2013, Rodrigues et al. 2013).

TABLE II

Geographic distribution of main methicillin-resistant Staphylococcus aureus (MRSA) lineages and clones $^{a}$

\begin{tabular}{|c|c|c|c|}
\hline $\mathrm{CC}$ & Lineage & Clone & Geographic distribution \\
\hline $\mathrm{CC} 1$ & ST1-SCCmecIV & $\begin{array}{c}\text { USA400 (CA-MRSA), } \\
\text { Brazilian USA400 (HA-MRSA) }\end{array}$ & $\begin{array}{l}\text { Australia, Canada, Europe, } \\
\text { South America, USA }\end{array}$ \\
\hline \multirow[t]{4}{*}{$\mathrm{CC} 5$} & ST5-SCCmecII & $\begin{array}{l}\text { USA100, NY/Japan } \\
\text { (HA-MRSA) }\end{array}$ & $\begin{array}{l}\text { Australia, Canada, Europe, Japan, } \\
\text { South America, South Korea, USA }\end{array}$ \\
\hline & ST5-SCCmecIV & $\begin{array}{l}\text { USA800, paediatric (HA-MRSA), } \\
\text { USA800-related (CA-MRSA) }\end{array}$ & Europe, South America, USA \\
\hline & ST5-SCCmecI & UK-EMRSA-3 or Cordobes/Chile (HA-MRSA) & $\begin{array}{l}\text { Asia, Europe, South Africa, } \\
\text { South America }\end{array}$ \\
\hline & ST228-SCCmecI & $\begin{array}{l}\text { Italian/Southern German } \\
\text { (HA-MRSA) }\end{array}$ & Europe \\
\hline \multirow[t]{5}{*}{$\mathrm{CC} 8$} & ST8-SCCmecIV & $\begin{array}{l}\text { USA500, UK-EMRSA-2/6 } \\
\text { (HA-MRSA) }\end{array}$ & Australia, Canada, Europe, USA \\
\hline & ST8-SCCmecIV & $\begin{array}{c}\text { USA300 } \\
\text { (CA-MRSA) }\end{array}$ & Asia, Australia, Europe, USA \\
\hline & ST247-SCCmecI & Iberian, UK-EMRSA-5 (HA-MRSA) & Europe, USA \\
\hline & ST239-SCCmecIII & $\begin{array}{l}\text { Brazilian/Hungarian (HA-MRSA), Russian-variant } \\
\text { (urethritis-related CA-MRSA) }\end{array}$ & $\begin{array}{l}\text { Asia, Australia, Europe, } \\
\text { South Africa, South America }\end{array}$ \\
\hline & ST612-SCCmecIV & - & Australia, South Africa \\
\hline \multirow[t]{2}{*}{$\mathrm{CC} 22$} & ST22-SCCmecIV & $\begin{array}{l}\text { UK-EMRSA-15 } \\
\text { (HA-MRSA) }\end{array}$ & Australia, Asia, Canada, Europe \\
\hline & ST36-SCCmecIV & $\begin{array}{l}\text { USA200, UK-EMRSA-16 } \\
\text { (HA-MRSA) }\end{array}$ & $\begin{array}{l}\text { Australia, Canada, UK, } \\
\text { USA }\end{array}$ \\
\hline \multirow[t]{2}{*}{$\mathrm{CC} 30$} & ST36-SCCmecII & - & $\begin{array}{l}\text { Asia, Australia, Europe, } \\
\text { South Africa }\end{array}$ \\
\hline & ST30-SCCmecIV & USA1100, OSPC (CA-MRSA) & South America, USA \\
\hline CC45 & ST45-SCCmecIV & USA600, Berlin & Europe, USA \\
\hline CC59 & ST59-SCCmecIV/VII & $\begin{array}{l}\text { USA1000 } \\
\text { (CA-MRSA) }\end{array}$ & Asia, Australia, Europe, USA \\
\hline $\mathrm{CC} 80$ & ST80-SCCmecIV & Europe (CA-MRSA) & Asia, Australia, Europe \\
\hline
\end{tabular}

$a$ : adapted of Deurenberg and Stobberingh (2008) and Stefani et al. (2012); CA-MRSA: community-acquired MRSA; CC: clonal complex; HA-MRSA: hospital-acquired MRSA; SCCmec: staphylococcal cassette chromosome mec; ST: sequence typing. 
Studies of single nucleotide polymorphisms (SNP) of ST5 MRSA isolates have suggested that their spread have most likely occurred by various SCCmec insertions into different methicillin-susceptible $S$. aureus (MSSA) strains in different regions of the world and not by the global spread of a ST5-MRSA strain over extensive geographical regions (Nübel et al. 2008). Conversely, phylogenetic evidence, also based on SNP analyses, has suggested the intercontinental spread of isolates of the ST239-SCCmecIII lineage (Harris et al. 2010, Gray et al. 2011).

It is well known that MRSA differs considerably from MSSA strains, whose associated infections are heteroclonal in nature. In a comparative study, MRSA was responsible for higher in-hospital mortality $(23.9 \%$ vs. $8.9 \% ; p=0.003)$ and longer bacteraemia $(4.7 \pm 6.5$ days vs. $2.7 \pm 2.9$ days; $p=0.01$ ) when compared with MSSA and it was concluded that SCCmec-associated virulence factors seem to play a role in the outcome of S. aureus BSI infection (Ganga et al. 2009). It was previously suggested that the increased ability of the highlevel resistant ST239 lineage to adhere to and invade human epithelial cells and to accumulate large amounts of biofilm might have contributed to its fitness as the most successful MRSA pathogen worldwide (Amaral et al. 2005). In fact, recent studies have implicated the presence of $m e c A$ and PBP2a in poly-N-acetylglucosamineindependent biofilm formation. In addition, coherent with the increased production of biofilm by the homogeneously, high-level resistant mecA construction (HoR 8325-4 derivative), it was demonstrated that its protease level was decreased concomitantly with impairment of the Agr virulence regulatory system (Pozzi et al. 2012).

In infections associated with multiresistant MRSA clones, such as those associated with ST239 isolates or in cases of severe MRSA infections, vancomycin is still the major therapeutic choice. However, because vancomycin is administered in intravenous form, the use of this drug requires patient hospitalisation and, thus, significantly increases treatment costs. Although still rare, vancomycin-resistant MRSA isolates [vancomycin-resistant S. aureus (VRSA;)] have been reported in the USA and some countries in Asia (Tenover et al. 2004, Whitener et al. 2004, Tiwari \& Sen 2006, Weigel et al. 2007, Saha et al. 2008, Askari et al. 2013, CDC 2013). In December 2012, the microbiology laboratory of the Clinics Hospital of the São Paulo University, Brazil, detected the first case of VRSA in Latin America: a methicillin and vancomycin-resistant strain that was isolated from blood culture (PAHO/WHO 2013). An increased incidence of vancomycin-intermediate $S$. aureus (VISA) or heterogeneous VISA (hVISA) has been documented in different countries (Richter et al. 2011, Hu et al. 2013, Oksuz et al. 2013). Despite the fact that some studies have reported the detection of VRSA and VISA isolates in Brazil (Lutz et al. 2003, Marques et al. 2013, PAHO/WHO 2013), vancomycin is still extremely active against MRSA isolates in this country (Gales et al. 2009).

In spite of the declining interest of the pharmaceutical industry in the development of new drugs, new antimicrobial agents have been discovered for the treatment of MRSA infections (Rivera \& Boucher 2011). Some studies using pneumonia animal models have demonstrated that linezolid was more effective than vancomycin toward this type of infection due to its better penetration into the lung. Therefore, it was suggested that linezolid might be chosen for MRSA pneumonia cases with increased vancomycin minimum inhibitory concentration (Docobo-Pérez et al. 2012, Martinez-Olondris et al. 2012, Rodvold \& McConeghy 2014). Daptomycin, which is a cyclic lipopeptide, was launched in the USA in 2003 for the treatment of skin/soft tissue infections (SSTI) caused by MRSA and other microorganisms and good results have been reported for this drug for the treatment of BSI and endocarditis caused by these microorganisms (Rodvold $\&$ McConeghy 2014). Tigecycline, which is a semisynthetic cyclin-glycyl that was released for use in the USA, Europe and Brazil, was not included in recent guidelines due to US Food and Drug Administration (FDA) safety issues (fda.gov/Safety/MedWatch/SafetyInformation/ SafetyAlertsforHumanMedicalProducts/ucm 370170. $\mathrm{htm}$; last access in January 13, 2014). As reported by the FDA, a higher risk of death was found among patients receiving tigecycline compared with other antimicrobials: $2.5 \%(66 / 2640)$ vs. $1.8 \%(48 / 2628)$, respectively. In most cases, the deaths resulted from worsening infections, complications of infections or other underlying medical conditions.

Another new drug, telavancin (once-daily parenteral lipoglycopeptide), was approved by the FDA in June 2013 for limited use when no other options are available. Ceftaroline fosamil is the first FDA-approved cephalosporin with activity against MRSA; however, clinical experience with the use of this antibiotic for invasive infections by MRSA has been limited. For more detailed information on MRSA antimicrobial therapy, see the Guidelines of the Infectious Diseases Society of America (Liu et al. 2011) and the recent review by Rodvold and McConeghy (2014).

$C A-M R S A$ - Community-acquired infection by MRSA is classically defined as an infection that affects community patients who have no history of previous MRSA infection or colonisation, surgery or hospitalisation, have not have been admitted into a long-term care facility or submitted to a percutaneous device, indwelling catheter or dialysis, within the year before infection (Maree et al. 2007). Generally, when compared with HA-MRSA, CA-MRSA lineages have different characteristics (Tristan et al. 2007). Frequently, these strains are isolated from SSTI; however, although less frequent, more serious infections such as bacteraemia, necrotising pneumonia and fasciitis, endocarditis and osteomyelitis have been reported in different countries (CDC 1999, Dauwalder et al. 2008, Bassetti et al. 2010, Sola et al. 2012), including Brazil (Ribeiro et al. 2005, Rozenbaum et al. 2009, Ferreira et al. 2012). Moreover, these isolates commonly carry SCCmec type IV, V or VII, often harbour $l u k S$ and $l u k F\left(l u k S F_{\text {pvl }}\right)$ genes that encode the $\mathrm{S}$ and F subunits of Panton-Valentine leukocidin (PVL) and are usually more susceptible to non- $\beta$-lactam antibiotics than HA-MRSA (Tristan et al. 2007, Sun et al. 2013).

The first CA-MRSA isolates that were detected were described at the end of the 1970s and beginning of the 
1980s in Western Australia and caused infections in the Aboriginal population. The clone in question was termed Western Australia-1 (WA-1) (CC1-ST1-SCCmecIV, PVL negative). Afterward, two other CA-MRSA clones emerged in Australia: the Queensland (CC93ST93-SCCmecIV, PVL positive) and Oceania Southwest Pacific (OSP) (CC30-ST30-SCCmecIV and PVL positive) (Udo et al. 1993, Nimmo et al. 2000, Munckhof et al. 2003). In 1999, the Minnesota Department of Health and the CDC reported the deaths of four children due to pulmonary infections that were characterised as necrotising pneumonia with septicaemia and were associated with a specific CA-MRSA clone, named mid-western 2 (MW2), which belonged to the ST1-SCCmecIV lineage that is to WA-1, but is a PVL producer (CDC 1999).

In the early 2000s, a rapid increase in the detection of CA-MRSA isolates occurred globally, including Brazil and a number of clones were documented (Naas et al. 2005, Ribeiro et al. 2005, Takizawa et al. 2005, Fleming et al. 2006, Klevens et al. 2006) (Table II). In the USA, the ST1-SCCmecIV isolates spread over different regions and the MW2 clone was renamed USA400. Two other CA-MRSA clones have spread in the USA, USA1100 (related to OSP) and USA300 (CC8-ST8-SCCmecIV, PVL positive), with USA300 being the predominant CA-MRSA isolate (Mishaan et al. 2005, Klevens et al. 2006, Casey et al. 2013). The main CA-MRSA isolates that are circulating in Brazil are related to the OSPC/USA1100 clone. However, isolates of the USA300 clone have been reported in two Brazilian cities (Ribeiro et al. 2005, 2007). The first case of severe infection (generalised osteomyelitis) caused by CA-MRSA in Brazil was reported in 2009. The recovered isolate was related to USA1100 clone (ST30 lineage) and showed susceptibility to all non- $\beta$-lactam antibiotics (Rozenbaum et al. 2009). Shortly after, a rare and severe case of pyomyositis, that was associated with compartment syndrome, was also described in Rio de Janeiro city, Brazil, in a previously healthy child (de Araújo et al. 2010). Unfortunately, few studies regarding the prevalence of CAMRSA have been reported in Brazil; therefore, little is known about the lineages involved and their prevalence in humans and animals (Ribeiro et al. 2007, Silva-Carvalho et al. 2009, de Araújo et al. 2010, Ferreira et al. 2012, Camargo et al. 2013). Recent data from Argentina have reported the predominance of ST30-SCCmecIV in community-acquired invasive infections (Fernandez et al. 2013). Similarly, studies carried out in Uruguay have described the spread of OSP/USA1100 in that country (Pardo et al. 2009).

The CA-MRSA lineage ST80-SCCmecIV is common in Europe (European clone) (Goering et al. 2009, Lamy et al. 2012, Rolo et al. 2012). However, in Asian and Pacific regions, including Australia and Taiwan, the ST59-SCCmecIV lineage has often been detected. Together, these data show that MRSA lineages may vary in different geographic regions and that, not rarely, a predominant strain can be supplanted by the expansion of a new lineage. In most countries, cases of CA-MRSA infections have been linked to small outbreaks. In the USA, Taiwan, Canada and Australia, CA-MRSA has become endemic in certain populations (O'Brien et al. 1999, Huang et al. 2008, Hung et al. 2012, Marra et al. 2012, Casey et al. 2013). A high rate (42\%) of CA-MRSA colonisation of different anatomical sites was found in a Western Australian village (O'Brien et al. 1999) and, in Taiwan, the rate of CA-MRSA isolation in children increased significantly from $9.8 \%$ in $1999-2000$ to $56 \%$ in 2004-2005 (Huang et al. 2008). The average annual increase in CA-MRSA incidence in the USA was 34\% (range 6-94\%) from 2005-2009 (Casey et al. 2013).

Despite the fact that CA-MRSA isolates are generally susceptible to non- $\beta$-lactam antibiotics, these strains may eventually acquire a multidrug resistance (MDR) phenotype. In Japan, for example, a CA-MRSA strain (ST30SCCmecIV, PVL positive) was described to harbour various antimicrobial resistance genes that were carried by an MDR plasmid (Takizawa et al. 2005). A study in a paediatric hospital in mainland China found rates of MDR $>50 \%$ among CA-MRSA isolates belonging to ST59, ST338, ST45, ST910 and ST965 (Wang et al. 2012).

Another significant change in the epidemiology of MRSA was the entrance of CA-MRSA lineages into hospital settings in different regions (Donnio et al. 2004, Maree et al. 2007, Song et al. 2011, Campanile et al. 2012) (A in Figure). The incidence of isolates carrying SCCmecIV (CA-MRSA sign) in hospitals in the USA increased from $<20 \%$ (1999) to $>50 \%$ (2004) (Maree et al. 2007) and similar results were reported in a French hospital between 1992-2002 (Donnio et al. 2004). Another study from Italy confirmed the migration of MRSA isolates carrying SCCmecIV from the community to hospitals (Campanile et al. 2012). In East Asia, the CA-MRSA

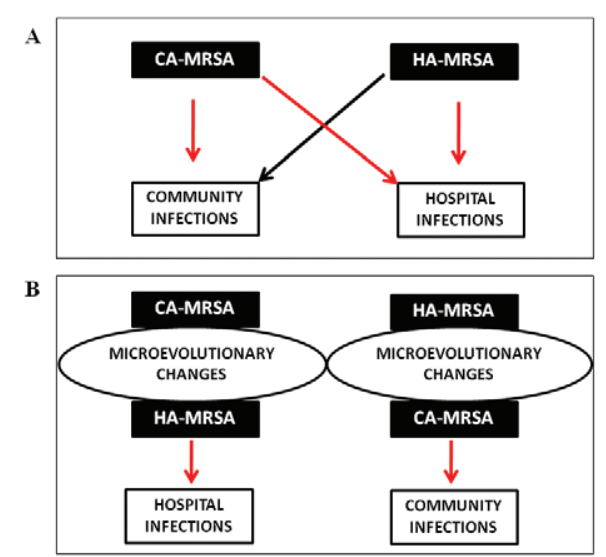

The multifaceted epidemiological scenarios of methicillin-resistant Staphylococcus aureus (MRSA) infections. Red arrows indicate endemic and black arrow transient infections. A: some typical community-acquired MRSA (CA-MRSA) strains can became endemic in both community and hospital settings. On the other hand, a number of hospital-acquired MRSA (HA-MRSA) clones can transiently circulate in the community; $\mathrm{B}$ : as consequence of the impact of the broad use of antimicrobial drugs and widespread of MRSA clones, microevolutionary changes are accumulating in the MRSA genome, occasionally leading to the emergence of novel variants of CA-MRSA or HA-MRSA lineages, presenting distinct epidemiological characteristics from the previous clone. 
lineages ST59-SCCmecIV, ST30-SCCmecIV and ST72SCCmecIV have also spread in hospitals (Song et al. 2011). In addition, reports indicating the USA300 and USA400 isolates causing infections associated with healthcare services have periodically been published (El-Mahdy et al. 2013, Machuca et al. 2013, Oksuz et al. 2013). In Brazil, studies have revealed that PVL-positive CA-MRSA isolates of the lineage ST30-SCCmecIV were also involved in hospital-associated infections (Scribel et al. 2009, Silva-Carvalho et al. 2009).

The emergence of a novel variant of the ST1-SCCmecIV lineage that was related to the USA400/MW2/ WA-1 clones was reported in Rio de Janeiro city in 2009. These isolates were able to overcome the previously predominant MRSA lineage, ST239-SCCmecIII (BEC), at the studied hospitals. Surprisingly, contrary to USA 400 CA-MRSA, the Brazilian ST1-SCCmecIV variant had typical characteristics of a HA-MRSA lineage, showing MDR traits, the absence of $l u k S F_{\mathrm{PVL}}$ and some enterotoxin genes. Moreover, most of these ST1 isolates from Brazil had tropism for nosocomial-related BSI (Silva-Carvalho et al. 2009) and the ability of these isolates to accumulate moderate/strong amounts of biofilm (in vitro and in vivo) was subsequently demonstrated (Ferreira et al. 2013). The acquisition of antibiotic resistance determinants, loss of toxin-associated genes and increased biofilm accumulation are most likely results of microevolutionary changes that could provide fitness advantages for the emergence of these USA400-related variants in nosocomial environments (B in Figure, left panel). To our knowledge, no report showing typical community-acquired infections caused by the Brazilian USA400-variant has been published. The only report involving the USA400 variant in the community was a community-onset of healthcare-associated endocarditis in a patient in Rio de Janeiro city who had an implanted haemodialysis catheter (Damasco et al. 2013).

A new epidemiological change was the emergence in the community of some MRSA lineages that were found for years to only be linked to hospital-associated infections (B in Figure, right panel). For example, epidemiological surveillances in Argentina have revealed the emergence of community-acquired infections caused by CA-MRSA isolates related to the hospital-associated paediatric clone (ST5-SCCmecIV); however, in contrast to the paediatric clone, this clone had acquired $l u k S F$ (Gardella et al. 2011, Sola et al. 2012). It was suggested that the acquisition of $l u k S F_{\mathrm{pvl}}$ and sea (encoding enterotoxin A) has contributed to the fitness of this novel clone as a major cause of community onset among children in Argentina (Gardella et al. 2011). Recently, ST5-SCCme$c \mathrm{IV}$ harbouring $l u k S F_{\mathrm{pvl}}$ was also reported in Brazil and was isolated from a case of sepsis in a 16-year-old male who had no history of exposure to healthcare or recent travel. More important was the fact that, as the Argentinean isolates, the hVISA phenotype was also detected in the Brazilian ST5 (Camargo et al. 2013). In Russia, isolates of the lineage ST239-SCCmecIII (related to the BEC), both spa3 and its variant spa351, have recently been isolated from urethritis in the community (Yamamoto et al. 2012). Although the genomic background of the Russian variant is similar to the hospital-associated ST239, named TW20, it has some marked diversity. What is striking is that the Russian variant incorporated isolates with high ability to transfer MDR elements by conjugation to $S$. aureus $16 \mathrm{~K}$, including a chloramphenicol resistance plasmid and the Tn554 transposon (Yamamoto et al. 2012). These findings demonstrate the dynamic microevolutionary mechanisms of the ST239 isolates in Russia and their potential as a drug resistance disseminator in community settings (Yamamoto et al. 2012). A study carried out in two major cities in Portugal found that public buses are often contaminated with MRSA clones that are currently found in hospitals of the particular geographic area. Therefore, MRSA contamination of public transportation and the transfer of bacteria to the hands of passengers may represent a route through which HA-MRSA isolates may spread to the community (Conceição et al. 2013).

As a consequence of the accelerated MRSA evolution, the epidemiology of MRSA infections has become increasingly complex, with some CA-MRSA gaining access to hospitals and a number of lineages that are typically found among HA-MRSA circulating in the community (Figure). Thus, establishing a clear and accurate definition between CA-MRSA and HA-MRSA strains has not been a simple task in some cases. Until now, molecular characterisation with epidemiological analyses has been considered the best criteria for differentiating the various MRSA lineages as hospital or community origin.

Experimental data using animal models have suggested that CA-MRSA strains were more virulent when compared to HA-MRSA (Day et al. 2012). While not all CA-MRSA carry genes for PVL, this neutrophil cytolysin is known as a virulence determinant related to the epidemiology of CA-MRSA infections because its detection is rare among HA-MRSA (Borghi et al. 2010, Portillo et al. 2013). However, its direct association with the severity of infections caused by this pathogen remains controversial in the scientific literature (Lina et al. 1999, Gillet et al. 2002, Wardenburg et al. 2008, Montgomery $\&$ Daum 2009). Some experimental results using animal models for SSTI, sepsis and pneumonia have demonstrated a minimal to no effect when mutants defective for PVL were compared with the respective isogenic wildtype strain (Voyich et al. 2006, Wardenburg et al. 2007, 2008, Diep et al. 2008a, Montgomery \& Daum 2009). However, other studies have shown that PVL contributes to tissue damage, skin infections and the severity of necrotising pneumonia (Lina et al. 1999, Gillet et al. 2002, Labandeira-Rey et al. 2007, Tseng et al. 2009).

A number of other factors, including $\alpha$-haemolysin or $\alpha$-toxin (Hla), phenol-soluble modulins (PSMs) and arginine catabolic mobile element (ACME), have been identified as important for CA-MRSA virulence and the latter was only detected in USA300 isolates (Wang et al. 2007, Wardenburg et al. 2007, Thurlow et al. 2013). Hla (encoded by the hla gene) is a proinflammatory, poreforming, cytolysin that acts in the lysis of immune system cells, such as macrophages, erythrocytes and lymphocytes (Bartlett et al. 2008). A study using an animal model of pneumonia, i.e., mice infected with hla knock- 
outs derived from CA-MRSA isolates of the USA300 or USA400 clones, suggested the involvement of Hla in this type of infection (Wardenburg et al. 2007). In addition, data from a recent study using hla and $l u k S F_{\text {pvl }}$ knockouts derived from USA300 CA-MRSA have suggested that Hla, and not PVL, impacts rabbit mortality from severe bacteraemia in a model of osteomyelitis. However, in this study, it was shown that PVL and Hla seemed to be required for early lung involvement via haematogenous spread (Crémieux et al. 2013).

The PSMs belong to a class of $\alpha$-helical, cytolytic peptides (20-25 amino acids) of the surfactant and amphipathic types that are produced by many species of Staphylococcus. All PSMs, mainly PMS $\alpha 3$, have proinflammatory activity, which includes activation and induction of chemotaxis and cytokine release from human neutrophils (Forsman et al. 2012). In 2007, Wang et al. (2007) found that removal of the psm $\alpha$ operon from two USA300 and USA400 isolates caused a strong, negative impact on neutrophil recruitment and lysis and in the evolution of skin infection and BSI. These results suggested that PSM $\alpha$ appears to contribute significantly to the pathogenesis of CA-MRSA infections.

It was suggested that the 31-kb genomic island, known as the ACME, is particularly important for the fitness of USA300. The ACME locus is identical to a genomic region in Staphylococcus epidermidis isolates, which are well known as skin surface colonisers (Barbier et al. 2011). The ACME locus of USA300 is composed of at least 33 putative genes and two operons, arc and opp. The arc operon is involved in arginine catabolism and it seems important for the ability of USA300 to succeed in acidic environments that mimic that found in the skin. It is thought that once USA300 S. aureus penetrates the epidermis, the Arc system leads to the syntheses of polyamines, which are the products of arginine metabolism. Polyamines are also made in human tissues and participate in wound healing and the inflammatory process (Barbier et al. 2011). It was also demonstrated that the ACME spe $G$ gene, which encodes a spermidine acetyltransferase (SPeG) could determine spermidine and spermine tolerance and such polyamines are lethal to $S$. aureus strains (Joshi et al. 2011). The opp operon seems to encode an oligopeptide and it was suggested that homologous genes were implicated in the virulence of Streptococcus pyogenes (Wang et al. 2005). It was recently demonstrated that spe $G$ also enhanced biofilm formation, adherence to fibrinogen/ fibronectin and keratinocyte-mediated killing (Planet et al. 2013). Indeed, it was found that the absence of ACME significantly decreased the in vivo fitness of USA300 isolates (Diep et al. 2008b).

Although some progress has been made, the mechanisms involved in the pathogenesis of CA-MRSA are not clearly determined. We still do not understand why some CA-MRSA clones, primarily those related to SSTI, have quickly emerged as successful pathogens in certain regions and what are the key determinants for the establishment of serious CA-MRSA infections among immunocompetent individuals.

Concluding remarks - MRSA remains one of the most challenging infection-control issues. This formidable pathogen is included in the group of so-called ESKAPE pathogens that is formed by Enterococcus faecium, $S$. aureus, Klebsiella pneumoniae, Acinetobacter baumannii, Pseudomonas aeruginosa and Enterobacter species. These bacteria are responsible for approximately $40 \%$ of nosocomial infections and represent the vast majority of isolates whose antimicrobial resistance represents serious therapeutic challenge (Hidron et al. 2008).

The global epidemiology of MRSA has continually been changing. Severe MRSA infections that were universally restricted to hospitals for decades are increasingly being reported among immunocompetent patients from the community. Additionally, studies on the molecular characterisation of MRSA have revealed epidemic clones of CA-MRSA causing community and hospitalacquired diseases. Moreover, the cross-transmission of CA-MRSA between humans and pets has also been a concern because these animals may serve as reservoir for human infections and vice versa.

More recently, the medical and veterinary communities were surprised by the emergence of LA-MRSA and $m e c \mathrm{C}$ MRSA. Furthermore, some typical HA-MRSA lineages have gained fitness advantages and emerged as CA-MRSA pathogens and the reverse is true: MRSA lineages previously detected only in the community have become more fit to survive in hospital settings.

The multiple epidemiological facets of this old pathogen was, at least in part, built up by the accumulation of microevolutionary changes in the MRSA genome and accelerated by the rapid spread of these bacteria in worldwide hospital and community settings, consequently leading to better fitness of the microorganism for surviving in different environmental scenarios. However, some small resources of antimicrobial agents that work against MRSA are still available.

\section{REFERENCES}

Amaral MM, Coelho LR, Flores RP, Souza RR, Silva-Carvalho MC, Teixeira LA, Ferreira-Carvalho BT, Figueiredo AM 2005. The predominant variant of the Brazilian epidemic clonal complex of methicillin-resistant Staphylococcus aureus has an enhanced ability to produce biofilm and to adhere to and invade airway epithelial cells. J Infect Dis 192: 801-810.

Armand-Lefevre L, Ruimy R, Andremont A 2005. Clonal comparison of Staphylococcus aureus isolates from healthy pig farmers, human controls and pigs. Emerg Infect Dis 11: 711-714.

Arriola CS, Güere ME, Larsen J, Skov RL, Gilman RH, Gonzalez AE, Silbergeld EK 2011. Presence of methicillin-resistant Staphylococcus aureus in pigs in Peru. PLoS ONE 6: e28529.

Askari E, Tabatabai SM, Arianpoor A, Naderi-Nasab M 2013. vanApositive vancomycin-resistant Staphylococcus aureus: systematic search and review of reported cases. Infect Dis Clin Pract 21: $91-93$

Barbier F, Lebeaux D, Hernandez D, Delannoy AS, Caro V, François P, Schrenzel J, Ruppé E, Gaillard K, Wolff M, Brisse S, Andremont A, Ruimy R 2011. High prevalence of the arginine catabolic mobile element in carriage isolates of methicillin-resistant Staphylococcus epidermidis. J Antimicrob Chemother 66: 29-36.

Bartlett AH, Foster TJ, Hayashida A, Park PW 2008. Alpha-toxin facilitates the generation of cxc chemokine gradients and stimulates neutrophil homing in Staphylococcus aureus pneumonia. J Infect Dis 198: 1529-1535. 
Bassetti M, Nicco E, Malgorzata M, Viscoli C, Valbusa A, Bongiorno D, Campanile F, Stefani S 2010. Community associated methicillin resistant Staphylococcus aureus (CA-MRSA) infective endocarditis in Italy. $J$ Infect 61: 353-355.

Becker AP, Santos O, Castrucci FM, Dias C, D’Azevedo PA 2012. First report of methicillin-resistant Staphylococcus aureus Cordobes/Chilean clone involved in nosocomial infections in Brazil. Epidemiol Infect 140: 1372-1375.

Berglund C, Ito T, Ikeda M, Ma XX, Söderquist B, Hiramatsu K 2008. Novel type of staphylococcal cassette chromosome mec in a methicillin-resistant Staphylococcus aureus strain isolated in Sweden. Antimicrob Agents Chemother 52: 3512-3516.

Borghi E, Cainarca M, Sciota R, Biassoni C, Morace G 2010. Molecular picture of community and healthcare-associated methicillinresistant Staphylococcus aureus circulating in a teaching hospital in Milan. Scand J Infect Dis 42: 873-878.

Breurec S, Zriouil SB, Fall C, Boisier P, Brisse S, Djibo S, Garin B 2011. Epidemiology of methicillin-resistant Staphylococcus aureus lineages in five major African towns: emergence and spread of atypical clones. Clin Microbiol Infect 17: 160-165.

Brown DFJ, Reynolds PE 1980. Intrinsic resistance to $\beta$-lactam antibiotics in Staphylococcus aureus. FEBS Lett 122: 275-278.

Caboclo RM, Cavalcante FS, Iorio NL, Schuenck RP, Olendzki AN, Felix MJ, Chamon RC, dos Santos KR 2013. Methicillin-resistant Staphylococcus aureus in Rio de Janeiro hospitals: dissemination of the USA400/ST1 and USA800/ST5 SCCmec type IV and USA100/ ST5 SCCmec type II lineages in a public institution and polyclonal presence in a private one. Am J Infect Control 41: e21-e26.

Caiaffa-Filho HH, Trindade PA, da Cunha PG, Alencar CS, Prado GV, Rossi F, Levin AS 2013. Methicillin-resistant Staphylococcus aureus carrying SCCmec type II was more frequent than the Brazilian endemic clone as a cause of nosocomial bacteremia. Diagn Microbiol Infect Dis 76: 518-520.

Camargo CH, da Cunha MDEL, Bonesso MF, da Cunha FP, Barbosa AN, Fortaleza CM 2013. Systemic CA-MRSA infection following trauma during soccer match in inner Brazil: clinical and molecular characterization. Diagn Microbiol Infect Dis 76: 372-374.

Campanile F, Bongiorno D, Falcone M, Vailati F, Pasticci B, Perez M, Stefani S 2012. Changing Italian nosocomial-community trends and heteroresistance in Sstaphylococcus aureus from bacteremia and endocarditis. Eur J Clin Microbiol Infect Dis 31: 739-745.

Casey JA, Cosgrove SE, Stewart WF, Pollak J, Schwartz BS 2013. A population-based study of the epidemiology and clinical features of methicillin-resistant Staphylococcus aureus infection in Pennsylvania, 2001-2010. Epidemiol Infect 141: 1166-1179.

CDC - Centers for Disease Control and Prevention 1999. Four pediatric deaths from community-acquired methicillin-resistant Staphylococcus aureus-Minnesota and North Dakota, 1997-1999. JAMA 282: 1123-1125.

CDC - Centers for Disease Control and Prevention 2007. MRSA: methicillin-resistant Staphylococcus aureus healthcare settings. JAMA 298: 1763-1771.

CDC - Centers for Disease Control and Prevention 2013. Antibiotic resistance threats in the United States. Available from: cdc.gov/ drugresistance/threat-report-2013/.

Conceição T, Diamantino F, Coelho C, de Lencastre H, Aires-de-Sousa M 2013. Contamination of public buses with MRSA in Lisbon, Portugal: a possible transmission route of major MRSA clones within the community. PLoS ONE 8: e77812.

Crémieux AC, Saleh-Mghir A, Danel C, Couzon F, Dumitrescu O, Lilin T, Perronne C, Etienne J, Lina G, Vandenesch F 2013. $\alpha$-hemolysin, not Panton-Valentine leukocidin, impacts rabbit mortality from severe sepsis with methicillin-resistant Staphylococcus aureus osteomyelitis. J Infect Dis PMID: 24376272.

Cuny C, Layer F, Strommenger B, Witte W 2011. Rare occurrence of methicillin-resistant Staphylococcus aureus CC130 with a novel mecA homologue in humans in Germany. PLoS ONE 6: e24360.

Cuny C, Strommenger B, Witte W, Stanek C 2008. Clusters of infections in horses with MRSA ST1, ST254 and ST398 in a veterinary hospital. Microb Drug Resist 14: 307-310.

D’Souza N, Rodrigues C, Mehta A 2010. Molecular characterization of methicillin-resistant Staphylococcus aureus with emergence of epidemic clones of sequence type (ST) 22 and ST772 in Mumbai, India. J Clin Microbiol 48: 1806-1811.

Damasco PV, Cavalcante FS, Chamon RC, Ferreira DC, Rioja SS, Potsch MV, Pastura MP, Marques VD, Castier MB, Marques EA, Santos KR 2013. The first case report of non-nosocomial healthcare-associated infective endocarditis due to methicillin-resistant Staphylococcus aureus USA400 in Rio de Janeiro, Brazil. Infection 41: 851-854.

Dauwalder O, Lina G, Durand G, Bes M, Meugnier H, Jarlier V, Coignard B, Vandenesch F, Etienne J, Laurent F 2008. Epidemiology of invasive methicillin-resistant Staphylococcus aureus clones collected in France in 2006 and 2007. J Clin Microbiol 46: 3454-3458.

David MZ, Taylor A, Lynfield R, Boxrud DJ, Short G, Zychowski D, Boyle-Vavra S, Daum RS 2013. Comparing pulsed-field gel electrophoresis with multilocus sequence typing, spa typing, staphylococcal cassette chromosome mec (SCCmec) typing and PCR for Panton-Valentine leukocidin, $\operatorname{arcA}$ and opp3 in methicillinresistant Staphylococcus aureus isolates at a US Medical Center. J Clin Microbiol 51: 814-819.

Day SR, Moore CM, Kundzins JR, Sifri CD 2012. Community-associated and healthcare-associated methicillin-resistant Staphylococcus aureus virulence toward Caenorhabditis elegans compared. Virulence 3: 576-582.

de Araújo BE, Borchert JM, Manhães PG, Ferreira FA, Ramundo MS, Silva-Carvalho MC, Seabra AC, Victal SH, Figueiredo AMS 2010. A rare case of pyomyositis complicated by compartment syndrome caused by ST30 staphylococcal cassette chromosome mec type IV methicillin-resistant Staphylococcus aureus. Am J Emerg Med 28: 537.

de Kraker ME, Wolkewitz M, Davey PG, Koller W, Berger J, Nagler J, Icket C, Kalenic S, Horvatic J, Seifert H, Kaasch AJ, Paniara O, Argyropoulou A, Bompola M, Smyth E, Skally M, Raglio A, Dumpis U, Kelmere AM, Borg M, Xuereb D, Ghita MC, Noble M, Kolman J, Grabljevec S, Turner D, Lansbury L, Grundmann H, Burden Study Group 2011. Clinical impact of antimicrobial resistance in European hospitals: excess mortality and length of hospital stay related to methicillin-resistant Staphylococcus aureus bloodstream infections. Antimicrob Agents Chemother 55: 1598-1605.

de Miranda OP, Carvalho MCS, Ribeiro A, Portela F, Caetano N, Cordeiro R, Vidal C, Figueiredo AMS 2007. Emergence of methicillin-resistant Staphylococcus aureus isolates carrying SCCmec IV in Brazil genetically related to USA 800. Clin Microbiol Infect 13: $1165-1172$.

Deurenberg RH, Stobberingh EE 2008. The evolution of Staphylococcus aureus. Infect Gen Evol 8: 747-763.

Diep BA, Chambers HF, Graber CJ, Szumowski JD, Miller LG, Han LL, Chen JH, Lin F, Lin J, Van Phan TH, Carleton HA, Mcdougal LK, Tenover FC, Cohen DE, Mayer KH, Sensabaugh GF, Perdreau-Remington F 2008a. Emergence of multidrug-resistant, community-associated, methicillin-resistant Staphylococcus aureus clone USA300 in men who have sex with men. Ann Intern Med 148: 249-257. 
Diep BA, Stone GS, Basuino L, Graber CJ, Miller A, des Etages SA, Jones A, Palazzolo-Balance AM, Perdreau-Remington F, Sensabaugh GF, de Leo FR, Chambers HF 2008b. The arginine catabolic mobile element and staphylococcal chromosomal cassette mec linkage: convergence of virulence and resistance in the USA300 clone of methicillin-resistant Staphylococcus aureus. J Infect Dis 197: 1523-1530.

Docobo-Pérez F, López-Rojas R, Domínguez-Herrera J, JiménezMejias ME, Pichardo C, Ibáñez-Martínez J, Pachón J 2012. Efficacy of linezolid versus a pharmacodynamically optimized vancomycin therapy in an experimental pneumonia model caused by methicillin-resistant Staphylococcus aureus. J Antimicrob Chemother 67: 1961-1967.

Donnio PY, Preney L, Gautier-Lerestif AL, Avril JL, Lafforgue N 2004. Changes in staphylococcal cassette chromosome type and antibiotic resistance profile in methicillin-resistant Staphylococcus aureus isolates from a French hospital over an 11 year period. $J$ Antimicrob Chemother 53: 808-813.

ECDC/EMEA - European Centre for Disease Prevention and Control/European Medicines Agency 2009. Technical report. The bacterial challenge: time to react. Available from: ecdc.europa. eu/en/publications/publications/0909_ter_the_bacterial_challenge_time_to_react.pdf.

El-Mahdy TS, El-Ahmady M, Goering RV 2013. Molecular characterization of methicillin-resistant Staphylococcus aureus isolated over a 2-year period in a Qatar hospital from multinational patients. Clin Microbiol Infect 20: 169-173.

Enright M, Day N, Davies C, Peacock S, Sprat B 2000. Multilocus sequence typing for characterization of methicillin-resistant and methicillin-susceptible clones of Staphylococcus aureus. J Clin Microbiol 38: 1008-1015.

Fernandez S, de Vedia L, Furst MJL, Gardella N, di Gregorio S, Ganaha MC, Prieto S, Carbone E, Lista N, Rotrying F, Stryjewski ME, Mollerach M 2013. Methicillin-resistant Staphylococcus aureus ST30-SCCmec IVc clone as the major cause of communityacquired invasive infections in Argentina. Infect Genet Evol 14: 401-405.

Ferreira D, Frota ACC, Cavalcante FS, Abad ED, dos Santos KRN 2012. Necrotizing fasciitis secondary to community pneumonia by Panton-Valentine leukocidin-positive methicillin-resistant Staphylococcus aureus. Am J Respir Crit Care Med 186: 202-203.

Ferreira FA, Souza RR, Moraes BS, Ferreira AMA, Américo MA, Fracalanzza SEL, Couceiro JNSS, Figueiredo AMS 2013. Impact of $A g r$ dysfunction on virulence profiles and infections associated with a novel methicillin-resistant Staphylococcus aureus (MRSA) variant of the lineage ST1-SCCmecIV. BMC Microbiology 13: 93.

Ferreira JP, Anderson KL, Correa MT, Lyman R, Ruffin F, Reller LB, Fowler Jr VG 2011. Transmission of MRSA between companion animals and infected human patients presenting to outpatient medical care facilities. PLOS ONE 6: e26978.

Fleming SW, Brown LH, Tice SE 2006. Community-acquired methicillin-resistant Staphylococcus aureus skin infections: report of a local outbreak and implications for emergency department care. J Am Acad Nurse Pract 18: 297-300.

Forsman H, Christenson K, Bylund J, Dahlgren C 2012. Receptor-dependent and independent immunomodulatory effects of phenolsoluble modulin peptides from Staphylococcus aureus on human neutrophils are abrogated through peptide inactivation by reactive oxygen species. Infect Immun 80: 1987-1995.

Frénay HM, Bunschoten AE, Schouls LM, Van Leeuwen WJ, Vandenbroucke-Grauls CM, Verhoef J, Mooi FR 1996. Molecular typing of methicillin-resistant Staphylococcus aureus on the ba- sis of protein a gene polymorphism. Eur J Clin Microbiol Infect Dis 15: 60-64.

Gales AC, Sader HS, Ribeiro J, Zoccoli C, Barth A, Pignatari AC 2009. Antimicrobial susceptibility of Gram-positive bacteria isolated in Brazilian hospitals participating in the Sentry program (2005-2008). Braz J Infect Dis 13: 90-98.

Ganga R, Riederer K, Sharma M, Fakih MG, Johnson LB, Shemes S, Khatib R 2009. Role of SCCmec type in outcome of Staphylococcus aureus bacteremia in a single medical center. J Clin Microbiol 47: 590-595.

Garcia-Alvarez L, Holden MT, Lindsay H, Webb CR, Brown DF, Curran MD, Walpole E, Brooks K, Pickard DJ, Teale C, Parkhill J, Bentley SD, Edwards GF, Girvan EK, Kearns AM, Pichon B, Hill RL, Larsen AR, Skov RL, Peacock SJ, Maskell DJ, Holmes MA 2011. Methicillin-resistant Staphylococcus aureus with a novel mecA homologue in human and bovine populations in the UK and Denmark: a descriptive study. Lancet Infect Dis 11: 595-603.

García-Garrote F, Cercenado E, Marín M, Bal M, Trincado P, Corredoira J, Ballesteros C, Pita J, Alonso P, Vindel A 2013. Methicillin-resistant Staphylococcus aureus carrying the mecC gene: emergence in Spain and report of a fatal case of bacteraemia. $J$ Antimicrob Chemother 69: 45-50.

Gardella N, Murzicato S, Di Gregorio S, Cuirolo A, Desse J, Crudo F, Gutkind G, Mollerach M 2011. Prevalence and characterization of methicillin-resistant Staphylococcus aureus among healthy children in a city of Argentina. Infect Genet Evol 11: 1066-1071.

Ghaznavi-Rad E, Shamsudin MN, Sekawi Z, Khoon LY, Aziz MN, Hamat RA, Neela V 2010. Predominance and emergence of clones of hospital-acquired methicillin-resistant Staphylococcus aureus in Malaysia. J Clin Microbiol 48: 867-872.

Gillet Y, Issartel B, Vanhems P, Fournet JC, Lina G, Bes M, Vandenesch F, Piémont Y, Brousse N, Floret D, Etienne J 2002. Association between Staphylococcus aureus strains carrying gene for Panton-Valentine leukocidin and highly lethal necrotising pneumonia in young immunocompetent patients. Lancet 359: $753-759$.

Goering RV, Larsen AR, Skov R, Tenover FC, Anderson KL, Dunman PM 2009. Comparative genomic analysis of European and middle eastern community-associated methicillin-resistant Staphylococcus aureus (CC80:ST80-IV) isolates by high-density microarray. Clin Microbiol Infect 15: 748-755.

Gray RR, Tatem AJ, Johnson JA, Alekseyenko AV, Pybus OG, Suchard MA, Salemi M 2011. Testing spatiotemporal hypothesis of bacterial evolution using methicillin-resistant Staphylococcus aureus ST239 genome-wide data within a bayesian framework. Mol Biol Evol 28: 1593-1603.

Haenni M, Saras E, Châtre P, Médaille C, Bes M, Madec JY, Laurent F 2012. A USA300 variant and other human-related methicillinresistant Staphylococcus aureus strains infecting cats and dogs in France. J Antimicrob Chemother 67: 326-329.

Harris SR, Feil EJ, Holden MT, Quail MA, Nickerson EK, Chantratita N, Bentley SD 2010. Evolution of MRSA during hospital transmission and intercontinental spread. Science 327: 469-474.

Harrison EM, Paterson GK, Holden MTG, Larsen J, Stegger M, Larsen AR, Petersen A, Skov RL, Christensen JM, Zeuthen AB, Heltberg O, Harris SR, Zadoks RN, Parkhill J, Peacock SJ, Holmes MA 2013. Whole genome sequencing identifies zoonotic transmission of MRSA isolates with the novel mecA homologue mecC. EMBO Mol Med 5: 509-515.

He W, Chen H, Zhao C, Zhang F, Li H, Wang Q, Wang X, Wang H 2013. Population structure and characterisation of Staphylococcus aureus from bacteraemia at multiple hospitals in China: 
association between antimicrobial resistance, toxin genes and genotypes. Int J Antimicrob Agents 42: 211-219.

Hidron AI, Edwards JR, Patel J, Horan TC, Sievert DM, Pollock DA, Fridkin SK, National Healthcare Safety Network Team, participating National Heatlhcare Safety Network Facilities 2008. NHSN annual update: antimicrobial-resistant pathogens associated with healthcare associated infections: annual summary of data reported to the National Healthcare Safety Network at the Centers for Disease Control and Prevention, 2006-2007. Infect Control Hosp Epidemiol 29: 996-1011.

Hu J, Ma XX, Tian Y, Pang L, Cui LZ, Shang H 2013. Reduced vancomycin susceptibility found in methicillin-resistant and methicillin-sensitive Staphylococcus aureus clinical isolates in Northeast China. PLoS ONE 8: e73300.

Huang YC, Ho CF, Chen CJ, Su LH, Lin TY 2008. Comparative molecular analysis of community-associated and healthcare-associated methicillin-resistant Staphylococcus aureus isolates from children in northern Taiwan. Clin Microbiol Infect 14: 1167-1172.

Hung WC, Takano T, Higuchi W, Iwao Y, Khokhlova O, Teng LJ, Yamamoto T 2012. Comparative genomics of community-acquired ST59 methicillin-resistant Staphylococcus aureus in Taiwan: novel mobile resistance structures with IS1216V. PLoS ONE 7: e46987.

Ito T, Hiramatsu K, Tomasz A, de Lencastre H, Perreten V, Holden MT, Coleman DC, Goering R, Giffard PM, Skov R1, Zhang K, Westh H, O’Brien F, Tenover FC, Oliveira DC, Boyle-Vavra S, Laurent F, Kearns AM, Kreiswirth B, Ko KS, Grundmann H, Sollid JE, John Jr JF, Daum R, Soderquist B, Buist G, International Working Group on the Classification of Staphylococcal Cassette Chromosome Elements (IWG-SCC) 2012. Guidelines for reporting novel mecA gene homologues. Antimicrob Agents Chemother 56: 4997-4999.

Ito T, Katayama Y, Asada K, Mori N 2001. Structural comparison of three types of staphylococcal cassette chromosome mec integrated in the chromosome in methicillin-resistant Staphylococccus aureus. Antimicrob Agents Chemother 45: 1323-1336.

Ito T, Katayama Y, Hiramatsu K 1999. Cloning and nucleotide sequence determination of the entire mec DNA of pre-methicillin-resistant Staphylococcus aureus N315. Antimicrob Agents Chemother 43: 1449-1458.

Ito T, Ma XX, Takeuchi F, Okuma K, Yuzawa H, Hiramatsu K 2004. Novel type V staphylococcal cassette chromosome mec driven by a novel cassete chromosome recombinase, $c c r$ C. Antimicrob Agents Chemother 48: 2637-2651.

Jessen O, Rosendal K, Bulow P, Faber V, Eriksen KR 1969. Changing staphylococci and staphylococcal infections: a ten-year study of bacteria and cases of bacteremia. N Engl J Med 281: 627-635.

Jevons MP 1961. Celbenin-resistant staphylococci. Br Med 1: 124-125.

Joshi GS, Spontak JS, Klapper DG, Richardson AR 2011. Arginine catabolic mobile element encoded spe $G$ abrogates the unique hypersensitivity of Staphylococcus aureus to exogenous polyamines. Mol Microbiol 82: 9-20.

Kahla-Clemenceau N, Barre E, Prat H, Thibault M, Bourret C, Richardin F, Bourdain JL, Berardi-Grassias L 1999. Outbreak of methicillin-resistant Staphylococcus aureus in general hospital intensive care unit. Pathol Biol 47: 449-456.

Katayama Y, Ito T, Hiramatsu K 2000. A new class of genetic element, Staphylococccus cassette chromosome mec, encodes methicillin-resistant in Staphylococccus aureus. Antimicrob Agents Chemother 44: 1549-1555.

Klevens RM, Morrison MA, Fridkin SK, Reingold A, Petit S, Gershman K, Ray S, Harrison LH, Lynfield R, Dumyati G, Townes JM, Craig AS, Fosheim G, Mcdougal LK, Tenover FC 2006. Active bacterial core surveillance of the emerging infections program network. community-associated methicillin-resistant Staphylococcus aureus and healthcare risk factors. Emerg Infect Dis 12: 1991-1993.

Krziwanek K, Metz-Gercek S, Mittermayer H 2009. Methicillin-resistant Staphylococcus aureus ST398 from human patients, upper Austria. Emerg Infect Dis 15: 766-769.

Labandeira-Rey M, Couzon F, Boisset S, Brown EL, Bes M, Benito Y, Barbu EM, Vazquez V, Höök M, Etienne J, Vandenesch F, Bowden MG 2007. Staphylococcus aureus Panton-Valentine leukocidin causes necrotizing pneumonia. Science 315: 1130-1133.

Lamy B, Laurent F, Gallon O, Doucet-Populaire F, Etienne J, Decousser JW, The Collège de Bacteriologie Virologie Hygiène (COLBVH) Study Group 2012. Antibacterial resistance, genes encoding toxins and genetic background among Staphylococcus aureus isolated from community-acquired skin and soft tissue infections in France: a national prospective survey. Eur J Clin Microbiol Infect Dis 31: 1279-1284.

Laurent F, Chardon H, Haenni M, Bes M, Reverdy ME, Madec JY, Lagier E, Vandenesch F, Tristan A 2012. MRSA harboring mecA variant gene mecC in France. Emerg Infect Dis 18: 1465-1467.

Li S, Skov RL, Han X, Larsen J, Sorum M, Wulf M, Voss A, Hiramatsu K, Ito T 2011. Novel types of staphylococcal cassette chromosome mec elements identified in clonal complex 398 methicillin-resistant Staphylococcus aureus strains. Antimicrob Agents Chemother 55: 3046-3050.

Lina G, Piemont Y, Godail-Gamot F, Bes M, Peter MO, Gauduchon V, Vandenesch F, Etienne J 1999. Involvement of Panton-Valentine leukocidin-producing Staphylococcus aureus in primary skin infections and pneumonia. Clin Infect Dis 29: 1128-1132.

Liu C, Bayer A, Cosgrove SE, Daum RS, Fridkin SKK, Gorwitz RJ, Kaplan SL, Karchmer AW, Levine DP, Murray BE, Rybak M, Talan DA, Chambers HF 2011. Clinical practice guidelines by the infectious diseases society of America for the treatment of methicillin-resistant Staphylococcus aureus infections in adults and children: executive summary. Clin Infect Dis 52: 285-292.

Loeffler A, Mccarthy A, Lloyd DH, Musilová E, Pfeiffer DU, Lindsay JA 2013. Whole-genome comparison of meticillin-resistant Staphylococcus aureus CC22 SCCmecIV from people and their in-contact pets. Vet Dermatol 24: 538-e128.

Lutz L, Machado A, Kuplich N, Barth AL 2003. Clinical failure of vancomycin treatment of Staphylococcus aureus infection in a tertiary care hospital in southern Brazil. Braz J Infect Dis 7: 224-228.

Ma XX, Ito T, Tiensasitorn C, Jamklang M, Chongtrakool P, BoyleVavra S, Daum RS, Hiramatsu K 2002. Novel type of staphylococcal cassette chromosome mec identified in communityacquired methicillin-resistant Staphylococcus aureus strains. Antimicrob Agents Chemother 46: 1147-1152.

Machuca MA, Sosa LM, González CI 2013. Molecular typing and virulence characteristic of methicillin-resistant Staphylococcus aureus isolates from pediatric patients in Bucaramanga, Colombia. PLOS ONE 8: e73434.

Maree CL, Daum RS, Boyle-Vavra S, Matayoshi K, Miller LG 2007. Community-associated methicillin-resistant Staphylococcus aureus isolates causing healthcare-associated infections. Emerg Infect Dis 13: 236-242.

Marques JB, Dalmolin TV, Bonez PC, Agertt VA, de Campos MM, Santos RC 2013. Detection of Staphylococcus aureus with an intermediate profile to vancomycin (VISA) isolate from Santa Maria, RS. Braz J Microbiol 44: 277-279.

Marra F, Patrick DM, Chong M, Mckay R, Hoang L, Bowie WR 2012. Population-based study of the increased incidence of skin and 
soft tissue infections and associated antimicrobial use. Antimicrob Agents Chemother 56: 6243-6249.

Martinez-Olondris P, Rigol M, Soy D, Guerrero L, Agusti C, Quera MA, Bassi GL, Esperatti M, Luque N, Liapikou M, Filella X, Marco F, de la Bellacasa JP, Torres A 2012. Efficacy of linezolid compared to vancomycin in an experimental model of pneumonia induced by methicillin-resistant Staphylococcus aureus in ventilated pigs. Crit Care Med 40: 162-168.

Mato R, Sanches IS, Venditti M, Platt DJ, Brown A, Chung M, de Lencastre H 1998. Spread of the multiresistant Iberian clone of methicillin-resistant Staphylococcus aureus (MRSA) to Italy and Scotland. Microb Drug Resist 4: 107-112.

McAdam PR, Templeton KE, Edwards GF, Holden MT, Feil EJ, Aanensen DM, Bargawi HJ, Spratt BG, Bentley SD, Parkhill J, Enright MC, Holmes A, Girvan EK, Godfrey PA, Feldgarden M, Kearns AM, Rambaut A, Robinson DA, Fitzgerald JR 2012. Molecular tracing of the emergence, adaptation and transmission of hospital-associated methicillin-resistant Staphylococcus aureus. Proc Natl Acad Sci USA 109: 9107-9112.

Menegotto F, González-Cabrero S, Cubero Á, Cuervo W, Muñoz M, Gutiérrez MP, Simarro M, Bratos MA, Orduña A 2012. Clonal nature and diversity of resistance, toxins and adhesins genes of methicillin-resistant Staphylococcus aureus collected in a Spanish hospital. Infect Genet Evol 12: 1751-1758.

Mishaan AM, Mason Jr EO, Martinez-Aguilar G, Hammerman W, Propst JJ, Lupski JR, Stankiewicz P, Kaplan SL, Hulten K 2005. Emergence of a predominant clone of community-acquired Staphylococcus aureus among children in Houston, Texas. Pediatr Infect Dis J 24: 201-206.

Montgomery CP, Daum RS 2009. Transcription of inflammatory genes in the lung after infection with community-associated methicillin-resistant Staphylococcus aureus: a role for PantonValentine leukocidin? Infect Immun 77: 2159-2167.

Moodley A, Oosthuysen WF, Dusé AG, Marais E, South African MRSA Surveillance Group 2010. Molecular characterization of clinical methicillin-resistant Staphylococcus aureus isolates in South Africa. J Clin Microbiol 48: 4608-4611.

Moore CL, Osaki-Kiyan P, Perri M, Donabedian S, Haque NZ, Chen A, Zervos MJ 2010. USA600 (ST45) methicillin-resistant Staphylococcus aureus bloodstream infections in urban Detroit. J Clin Microbiol 48: 2307-2310.

Munckhof WJ, Schooneveldt J, Coombs GW, Hoare J, Mimmo GR 2003. Emergence of community-acquired methicillin-resistant Staphylococcus aureus (MRSA) infection in Queensland, Australia. Int J Infect Dis 7: 259-267.

Naas T, Fortineau N, Spicq C, Robert J, Jarlier V, Nordmann P 2005. Three-year survey of community-acquired methicillin-resistant Staphylococcus aureus producing Panton-Valentine leukocidin in a French university hospital. J Hosp Infect 61: 321-329.

Nimmo GR, Schooneveldt J, O’Kane G, McCall B, Vickery A 2000. Community acquisition of gentamicin-sensitive methicillin-resistant Staphylococcus aureus in southeast Queensland, Australia. J Clin Microbiol 38: 3926-3931.

NNIS - National Nosocomial Infection Surveillance 2004. System report, data summary, from January 1992 through June 2004, issued October 2004. Am J Infect Control 32: 470-485.

Nübel U, Roumagnac P, Feldkamp M, Song JH, Ko KS, Huang YC, Achtman M 2008. Frequent emergence and limited geographic dispersal of methicillin-resistant Staphylococcus aureus. Proc Natl Acad Sci USA 105: 14130-14135.

O’Brien FG, Pearman JW, Gracey M, Riley TV, Grubb WB 1999. Community strain of methicillin-resistant Staphylococcus aureus involved in a hospital outbreak. J Clin Microbiol 37: 2858-2862.
Oksuz L, Dupieux C, Tristan A, Bes M, Etienne J, Gurler N 2013. The high diversity of MRSA clones detected in a university hospital in Istanbul. Int J Med Sci 10: 1740-1745.

Oliveira DC, Milheiriço C, de Lencastre H 2006. Redefining a structural variant of staphylococcal cassette chromosome mec, SCCmec type VI. Antimicrob Agents Chemother 50: 3457-3459.

O'Toole RD, Drew WL, Dahlgren BJ, Beaty HN 1970. An outbreak of methicillin-resistant Staphylococcus aureus infection - Observations in hospital and nursing home. JAMA 213: 257-263.

PAHO/WHO-PanAmericaHealthOrganization/WorldHealth Organization 2013. Epidemical alert: vancomycin-resistant Staphylococcus aureus. Available from: paho.org/hq/index.php?option=com docman\&task $=$ doc_view\&gid $=22187 \&$ itemid $=$.

Pardo L, Machado V, Mollerach M, Mota MI, Tuchscherr LP, Gadea P, Gardella N, Sordelli DO, Vola M, Schelotto F, Varela G 2009. Characteristics of community-associated methicillin-resistant Staphylococcus aureus (CA-MRSA) strains isolated from skin and soft-tissue infections in Uruguay. Int J Microbiol 2009: 472126.

Paterson GK, Larsen AR, Robb A, Edwards GE, Pennycott TW, Foster G, Mot D, Hermans K, Baert K, Peacock SJ, Parkhill J, Zadoks RN, Holmes MA 2012. The newly described mecA homologue, mecALGA251, is present in methicillin-resistant Staphylococcus aureus isolates from a diverse range of host species. J Antimicrob Chemother 67: 2809-2813.

Planet PJ, Larussa SJ, Dana A, Smith H, Xu A, Ryan C, Uhlemann AC, Boundy S, Goldberg J, Narechania A, Kulkarni R, Ratner AJ, Geoghegan JA, Kolokotronis SO, Prince A 2013. Emergence of the epidemic methicillin-resistant Staphylococcus aureus strain USA300 coincides with horizontal transfer of the arginine catabolic mobile element and spe $G$-mediated adaptations for survival on skin. MBio 4: e00889-13.

Portillo BC, Moreno JE, Yomayusa N, Alvarez CA, Cardozo BE, Pérez JA, Díaz PL, Ibañez M, Mendez-Alvarez S, Leal AL, Gómez NV 2013. Molecular epidemiology and characterization of virulence genes of community-acquired and hospital-acquired methicillin-resistant Staphylococcus aureus isolates in Colombia. Int J Infect Dis 17: e744-749.

Pozzi C, Waters EM, Rudkin JK, Schaeffer CR, Lohan AJ, Tong P, Loftus BJ, Pier GB, Fey PD, Massey RC, O’Gara JP 2012. Methicillin resistance alters the biofilm phenotype and attenuates virulence in Staphylococcus aureus device-associated infections. PLoS Pathog 8: e1002626.

Quitoco IM, Raimundo MS, Silva-Carvalho MC, Souza RR, Beltrame CO, de Oliveira TF, Araújo R, del Peloso PF, Coelho LR, Figueiredo AM 2013. First report in South America of companion animal colonization by the USA1100 clone of communityacquired methicillin-resistant Staphylococcus aureus (ST30) and by the European clone of methicillin-resistant Staphylococcus pseudintermedius (ST71). BMC Res Notes 6: 336.

Rammelkamp CH, Maxon T 1942. Resistance of Staphylococcus aureus to the action of penicillin. Proc Royal Soc Exper Biol Med 51: 86-389.

Ribeiro A, Coronado AZ, Silva-Carvalho MC, Ferreira-Carvalho BT, Dias C, Rozenbaum R, del Peloso PF, Leite CCF, Teixeira LA, Figueiredo AMS 2007. Detection and characterization international community-acquired infections by methicillin-resistant Staphylococcus aureus clones in Rio de Janeiro and Porto Alegre cities causing both community and hospital-associated diseases. Diagn Microbiol Infect Dis 59: 339-345.

Ribeiro A, Dias C, Silva-Carvalho MC, Berquó L, Ferreira FA, Santos RNS, Ferreira-Carvalho B, Figueiredo AMS 2005. First report of infection with community-acquired methicillin-resistant 
Staphylococccus aureus in South America. J Clin Microbiol 43: 1985-1988.

Richter SS, Satola SW, Crispell EK, Heilmann KP, Dohrn CL, Riahi F, Costello AJ, Diekema DJ, Doern GV 2011. Detection of Staphylococcus aureus isolates with heterogeneous intermediate-level resistance to vancomycin in the United States. J Clin Microbiol 49: 4203-4207.

Rivera AM, Boucher HW 2011. Current concepts in antimicrobial therapy against select Gram-positive organisms: methicillin-resistant Staphylococcus aureus, penicillin-resistant pneumococci and vancomycin-resistant enterococci. Mayo Clin Proc 86: 1230-1243.

Rodrigues MV, Fortaleza CM, Riboli DF, Rocha RS, Rocha C, da Cunha ML 2013. Molecular epidemiology of methicillin-resistant Staphylococcus aureus in a burn unit from Brazil. Burns 39: 1242-1249.

Rodríguez-Noriega E, Seas C, Guzmán-Blanco M, Mejía C, Alvarez C, Bavestrello L, Zurita J, Labarca J, Luna CM, Salles MJ, Gotuzzo E 2010. Evolution of methicillin-resistant Staphylococcus aureus clones in Latin America. Int J Infect Dis 14: e560-566.

Rodvold KA, McConeghy KW 2014. Methicillin-resistant Staphylococcus aureus therapy: past, present and future. Clin Infect Dis 58 (Suppl. 1): S20-S27.

Rolo J, Miragaia M, Turlej-Rogacka A, Empel J, Bouchami O, Faria NA, Tavares A, Hryniewicz W, Fluit AC, de Lencastre H, Concord Working Group 2012. High genetic diversity among community associated Staphylococcus aureus in Europe: results from a multicenter study. PLOS ONE 7: e34768.

Rozenbaum R, Sampaio MG, Batista GS, Garibaldi AM, Terra GM, Souza MJ, Vieira EN, Silva-Carvalho MC, Teixeira LA, Figueiredo AMS 2009. First report in Brazil of severe infection cause by community-acquired methicillin-resistant Staphylococcus aureus (CA-MRSA). Braz J Med Biol Res 42: 756-760.

Sabat AJ, Koksal M, Akkerboom V, Monecke S, Kriegeskorte A, Hendrix R, Ehricht R, Köck R, Becker K, Friedrich AW 2012. Detection of new methicillin-resistant Staphylococcus aureus strains that carry a novel genetic homologue and important virulence determinants. J Clin Microbiol 50: 3374-3377.

Saha B, Singh AK, Ghosh A, Bal M 2008. Identification and characterization of a vancomycin-resistant Staphylococcus aureus isolated from Kolkata (South Asia). J Med Microbiol 57: 72-79.

Sanches IS, Ramirez M, Troni H, Abecassis M, Padua M, Tomasz A, de Lencastre H 1995. Evidence for the geographic spread of a methicillin-resistant Staphylococccus aureus clone between Portugal and Spain. J Clin Microbiol 33: 1243-1246.

Scribel LV, Silva-Carvalho MC, Souza RR, Superti SV, Kvitko CH, Figueiredo AM, Zavascki AP 2009. Clinical and molecular epidemiology of methicillin-resistant Staphylococcus aureus carrying SCCmecIV in a university hospital in Porto Alegre, Brazil. Diagn Microbiol Infect Dis 65: 457-461.

Shittu A, Oyedara O, Abegunrin F, Okon K, Raji A, Taiwo S, Ogunsola F, Onyedibe K, Elisha G 2012. Characterization of methicillinsusceptible and resistant staphylococci in the clinical setting: a multicentre study in Nigeria. BMC Infect Dis 12: 286.

Shore AC, Deasy EC, Slickers P, Brennan G, O’Connell B, Monecke S, Ehricht R, Coleman DC 2011. Detection of staphylococcal cassette chromosome mec type XI carrying highly divergent mecA, $m e c I, m e c R I, b l a Z$ and $c c r$ genes in human clinical isolates of clonal complex 130 methicillin-resistant Staphylococcus aureus. Antimicrob Agents Chemother 55: 3765-3773.

Silva-Carvalho MC, Bonelli RR, Souza RR, Moreira S, dos Santos LC, Conceição M, de Mello Jr SJ, Carballido JM, Rito PN, Vieira VV, Teixeira LA, Figueiredo AMS 2009. Emergence of multire- sistant variants of the community-acquired methicillin-resistant Staphylococcus aureus lineage ST1-SCCmecIV in 2 hospitals in Rio de Janeiro, Brazil. Diagn Microbiol Infect Dis 65: 300-305.

Skinner D, Keefer CS 1941. Significance of bacteremia caused by Staphylococcus aureus. Arch Intern Med 68: 851-875.

Sola C, Paganini H, Egea AL, Moyano AJ, Garnero A, Kevric I, Culasso C, Vindel A, Study Group of CA-MRSA in children, Argentina-2007, Lopardo H, Bocco JL 2012. Spread of epidemic MRSA-ST5-IV clone encoding PVL as a major cause of community onset staphylococcal infections in Argentinean children. PLOS ONE 7: e30487.

Song JH, Hsueh PR, Chung DR, Ko KS, Kang CI, Peck KR, ANSORP Study Group 2011. Spread of methicillin-resistant Staphylococcus aureus between the community and the hospitals in Asian countries: an ANSORP study. J Antimicrob Chemother 66: 1061-1069.

Stefani S, Chung DR, Lindsay JA, Friedrich AW, Kearns AM, Westh H, Mackenzie FM 2012. Methicillin-resistant Staphylococcus aureus (MRSA): global epidemiology and harmonization of typing methods. Int J Antimicrobiol Agents 39: 273-282.

Sun DD, Ma XX, Hu J, Tian Y, Pang L, Shang H, Cui LZ 2013. Epidemiological and molecular characterization of community and hospital-acquired Staphylococcus aureus strains prevailing in Shenyang, northeastern China. Braz J Infect Dis 17: 682-690.

Takizawa Y, Taneike I, Nakagawa S, Oishi T, Nitahara Y, Iwakura N, Ozaki K, Takano M, Nakayama T, Yamamoto TA 2005. PantonValentine leucocidin (PVL)-positive community-acquired methicillin-resistant Staphylococcus aureus (MRSA) strain, another such strain carrying a multiple-drug resistance plasmid and other more-typical PVL-negative MRSA strains found in Japan. J Clin Microbiol 43: 3356-3363.

Taubes G 2008. The bacteria fight back. Science 321: 356-361.

Teixeira LA, Resende CA, Ormond LR, Rosembaum R, Figueiredo AMS, de Lencastre H, Tomasz A 1995. Geographic spread of epidemic multirresistant Staphylococccus aureus clone in Brazil. J Clin Microbiol 33: 2400-2404.

Tenover FC, Weigel LM, Appelbaum PC, Mcdougal LK, Chaitram J, Mcallister S, Clark N, Killgore J, O'Hara CM, Jevitt L, Patel JB, Bozdogan B 2004. Vancomycin-resistant Staphylococccus aureus isolate from a patient in Pennsylvania. Antimicrob Agents Chemother 48: 275-280.

Thurlow LR, Joshi GS, Clark JR, Spontak JS, Neely CJ, Maile R, Richardson AR 2013. Functional modularity of the arginine catabolic mobile element contributes to the success of USA300 methicillin-resistant Staphylococcus aureus. Cell Host Microbe 13: $100-107$.

Tiwari HK, Sen MR 2006. Emergence of vancomycin-resistant Staphylococcus aureus (VRSA) from a tertiary care hospital from northern part of India. BMC Infect Dis 6: 156.

Tristan A, Ferry T, Durand G, Dauwalder O, Bes M, Lina G, Vandenesch F, Etienne J 2007. Virulence determinants in community and hospital methicillin-resistant Staphylococcus aureus. J Hosp Infect 65: 105-109.

Tseng CW, Kyme P, Low J, Rocha MA, Alsabeh R, Miller LG, Otto M, Arditi M, Diep BA, Nizet V, Doherty TM, Beenhouwer DO, Liu GY 2009. Staphylococcus aureus Panton-Valentine leukocidin contributes to inflammation and muscle tissue injury. PLoS ONE 4: e6387.

Turlej A, Hryniewicz W, Empel J 2011. Staphylococcal cassette chromosome mec (SCCmec) classification and typing methods: an overview. Pol J Microbiol 60: 95-103. 
Udo EE, Pearman JW, Grubb WB 1993. Genetic analysis of community isolates methicillin-resistant $S$. aureus in western Australia. J Hosp Infect 25: 97-108.

Van Rensburg MJ, Madikane VE, Whitelaw A, Chachage M, Haffejee S, Elisha BG 2011. The dominant methicillin-resistant Staphylococcus aureus clone from hospitals in Cape Town has an unusual genotype: ST612. Clin Microbiol Infect 17: 785-792.

Vandendriessche S, Vanderhaeghen W, Soares FV, Hallin M, Catry, B, Hermans K, Butaye P, Haesebrouck F, Struelens MJ, Denis O 2013. Prevalence, risk factors and genetic diversity of methicillinresistant Staphylococcus aureus carried by humans and animals across livestock production sectors. J Antimicrob Chemother 68 : $1510-1516$.

Voyich JM, Otto M, Mathema B, Braughton KR, Whitney AR, Welty D, Long RD, Dorward DW, Gardner DJ, Lina G, Kreiswirth BN, de Leo FR 2006. Is Panton-Valentine leukocidin the major virulence determinant in community-associated methicillin-resistant Staphylococcus aureus disease? J Infect Dis 194: 1761-1770.

Wang CH, Lin CY, Luo YH, Tsai PJ, Lin YS, Lin MT, Chuang WJ, Liu CC, Wu JJ 2005. Effects of oligopeptide permease in group a streptococcal infection. Infect Immun 73: 2881-2890.

Wang L, Liu Y, Yang Y, Huang G, Wang C, Deng L, Zheng Y, Fu Z, Li C, Shang Y, Zhao C, Sun M, Li X, Yu S, Yao K, Shen X 2012. Multidrug resistant clones of community-associated methicillinresistant Staphylococcus aureus isolated from Chinese children and the resistance genes to clindamycin and mupirocin. $J$ Med Microbiol 61: 1240-1247.

Wang R, Braughton KR, Kretschmer D, Bach TH, Queck SY, Li M, Kennedy AD, Dorward DW, Klebanoff SJ, Peschel A, de Leo FR, Otto M 2007. Identification of novel cytolytic peptides as key virulence determinants for community-associated MRSA. Nat Med 13: 1510-1514.
Wardenburg J, Bae T, Otto M, de Leo FR, Schneewind O 2007. Poring over pores: alpha-hemolysin and Panto-Valentine leukocidin in Staphylococcus aureus pneumonia. Nat Med 13: 1405-1406.

Wardenburg J, Palazzolo-Ballance AM, Otto M, Schneewind O, de Leo FR 2008. Panton-Valentine leukocidin is not a virulence determinant in murine models of community-associated methicillin-resistant Staphylococcus aureus disease. J Infect Dis 198: 1166-1170.

Weigel LM, Donlan RM, Shin DH, Jensen B, Clark NC, Mcdougal LK, Zhu W, Musser KA, Thompson J, Kohlerschmidt D, Dumas N, Limberger RJ, Patel JB 2007. High-level vancomycin-resistant Staphylococcus aureus isolates associated with a polymicrobial biofilm. Antimicrob Agents Chemother 51: 231-238.

Whitener CJ, Park SY, Browne FA, Parent LJ, Julian K, Bozdogan B, Appelbaum PC, Chaitram J, Weigel LM, Jernigan J, Mcdougal LK, Tenover FC, Fridkin SK 2004. Vancomycin-resistant Staphylococccus aureus in the absence of vancomycin exposure. Clin Infect Dis 38: 1049-1055.

Williamson DA, Bakker S, Coombs GW, Tan HL, Monecke S, Heffernan $H$ 2013. Emergence and molecular characterization of clonal complex 398 (CC398) methicillin-resistant Staphylococcus aureus (MRSA) in New Zealand. J Antimicrob Chemother: doi: $10.1093 / \mathrm{jac} / \mathrm{dkt} 499$.

Yamamoto T, Takano T, Higuchi W, Iwao Y, Singur O, Reva I, Otsuka Y, Nakayashiki T, Mori H, Reva G, Kuznetsov V, Potapov V 2012. Comparative genomics and drug resistance of a geographic variant of ST239 methicillin-resistant Staphylococcus aureus emerged in Russia. PLoS ONE 7: e29187.

Zhang K, Mcclure J, Elsayed S, Conly JM 2009. Novel staphylococcal cassette chromosome mec type, tentatively designated VIII type, harboring class A mec and type $4 \mathrm{ccr}$ gene complexes in a Canadian epidemic strain of methicillin-resistant Staphylococcus aureus. Antimicrob Agents Chemother 53: 531-540. 